ISSN 2410-1176 (Print) Вісник КНУКіМ. Серія Мистецтвознавство. Вип. 39. ISSN 2616-4183 (Online)

7. Letowski, J. (2010). Museum-Making: Transitioning from Private Collection to Public Museum. USA: George Washington University.

[online] Available at: <https://museumstudies.columbian.gwu.edu/sites/museumstudies.columbian. gwu.edu/files/downloads/Museum-Making.pdf>[Accessed 01 November 2018].

8. Melnychuk, L. (2015). Kolektsionuvannia tvoriv mystetstva yak skladova khudozhnoho zhyttia [Collecting works of art as a component of artistic life].Visnyk Kharkivskoi derzhavnoi akademii dyzainu i mystetstv, no. 9, pp. 43-47.

9. Petrashyk, V. (2015). Do istyny y sviatosti [To the truth and holiness]. Obrazotvorche mystetstvo, no. 2, pp. 58-61.

10. Petrashyk, V. (2016). Kultura - nash ambasador do Yevropy [Culture is our ambassador to Europe]. Interviu mystetstvoznavtsia V. Petrashyka z metsenatom M. Baldisom. Obrazotvorche mystetstvo, no. 2, pp.100-103.

11. Roslavets, O. (1999). Bohdan Ivanovych Khanenko - zasnovnyk Kyivskoho muzeiu Zakhidnoho ta Skhidnoho mystetstva [Bohdan Ivanovych Khanenko, the founder of the Kyiv Museum of Western and Oriental Art]. In: To the 150th anniversary of the birth of Bohdan Ivanovych Khanenko, patron of art, collector, founder of the museum: materials of the scientificpractical conference. Kyiv: Kyi.

12. Sarabyanov, D. (1991). Sobirayut kartinyi ne koryisti radi [Collect pictures not for personal gain]. Kaliningrad: Kaliningradskaya hudozhestvennaya galereya.

(C) Петрашик B. I., 2018

(С) Цугорка О. П., 2018

Стаття надійшла до редакиї: 20.06.2018

УДК 738.1:7.012.185 (477)"20"

Школьна Ольга Володимирівна

доктор мистецтвознавства,

Київський університет

імені Бориса Грінченка,

вул. Бульварно-Кудрявська, 18/2,

Київ, Украӥна, 04070,

https://orcid.org/0000-0002-7245-6010

dushaorchidei@ukr.net

\title{
РЕКОНСТРУКЦІЯ ПЕРШОГО ТОНКОКЕРАМІЧНОГО СКУЛЬПТУРНОГО ОБРАЗУ «УКРАЇНКИ» ЯК ПРОЕКТ ФІРМИ С. ВОРОНОВА «ІСТОРИЧНИЙ ФАРФОРОВИЙ ЗАВОД А. МІКЛАШЕВСЬКОГО»
}

Мета роботи - проаналізувати скульптурний образ «Українки» 1850-х рр., виготовлений на підприємстві у Волокитиному та його «репліки» у сучасних творах фірми «Alis-K ${ }^{\circ}$. Методологія дослідження грунтується на сукупності принципів, підходів i методів. Застосовано принцип наукової об'єктивності, культурологічний та мистецтвознавчий підходи, компаративний метод - для здійснення історико-порівняльних паралелей щодо розвитку фарфорового виробництва XIX ст. в Свропі, історико-культурний метод для висвітлення значення символіко-образної складової статуетки «Українки» та ії розпису, метод мистецтвознавчого аналізу - для осмислення специфіки формотворення i декорування на Волокитинському фарфоровому заводі та виробництві фірми «Alis- $\mathrm{K}^{\circ} »$. Наукова новизна полягає у введенні до наукового обігу всебічного наукового аналізу образної складової «Українки» підприємства тонкої кераміки А. Міклашевського та їі сучасних реплік, а також у спробах інтерпретації ідейного наповнення означених творів. Висновки. Поява у вітчизняному «білому золоті» скульптури малих форм «Українки»у національних строях датується близько 1850 р. Ця статуетка виготовлялася за старовинними 
класичними технологіями ручного формотворення з пластичними елементами доліплювання на Волокитинському фарфоровому заводі. Нині відомо 9 фігурок «Українки» в 6-ти варіантах розфарбування. Розпис виконувався місцевими майстрами з Чернігово-Сумської землі і надалі був еталонним для багатьох інших вітчизняних виробництв тонкої кераміки. Означена скульптура стала знаковим збірним образом представниць нашого народу, через яку пізнавали нашу національну ідентичність в європейському фарфорі й загалом у світі. Ліпився артефакт з натури. Прототипом виступила місцева красуня з українських кріпаків с. Волокитиного «Палажка». Через 160-170 рр. до теми першої увічненої у вітчизняній порцеляні «усміхненої кори» 3 народу повернулося виробництво С. Воронова «Alis-K ${ }^{\circ}$. Репліки і реконструкції історичної «Українки» були переведені в зменшений формат, 22,7 до менш, як 15 см (так звана арт-мініатюра). Художниками означеної установи запропоновані як рефлексії, так і оновлені варіанти розпису, що перегукуються з парними предметами мистецьких наборів - декоративними колекційними наперстками збільшеного розміру, оформленими за традиціями стилістики Волокитиного середини XIX ст.

Ключові слова: скульптура малих форм; фарфор; «Українка»; «Палажка»; «Марина Мнішек»; Волокитине; А. Міклашевський; С. Воронов.

Школьная Ольга Владимировна, доктор искусствоведения, Киевский университет имени Бориса Гринченко, ул. Бульварно-Кудрявская, 18/2, Киев, Украина

Реконструкция первого тонкокерамического скульптурного образа «Украинки» как проект фирмы С. Воронова «Исторический фарфоровый завод А. Миклашевского»

Цель работы - проанализировать скульптурный образ «Украинки» 1850-х гг., изготовленный на предприятии в Волокитино и его «реплики» в современных произведениях фирмы «Alis- $\mathrm{K}^{\circ} »$. Методология исследования основывается на совокупности принципов, подходов и методов. Применен принцип научной объективности, культурологический и искусствоведческий подходы, компаративный метод - для осуществления историкосравнительных параллелей относительно развития фарфорового производства XIX ст. в Европе, историко-культурный метод для освещения значения символико-образной составляющей статуэтки «Украинки» и ее росписи, метод искусствоведческого анализа - для осмысления специфики формообразования и декорирования на Волокитинском фарфоровом заводе и производстве фирмы «Alis- $\mathrm{K}^{\circ} »$. Научная новизна состоит во введении в научное обращение всестороннего научного анализа образной составляющей «Украинки» предприятия тонкой керамики А. Миклашевского и её современных реплик, а также в попытках интерпретации идейного наполнения обозначенных произведений. Выводы. Появление в отечественном «белом золоте» скульптуры малых форм «Украинки» в национальных одеждах датируется около 1850 г. Эта статуэтка изготовлялась по старинным классическим технологиям ручного формообразования с пластическими элементами долепливания на Волокитинском фарфоровом заводе. Ныне известно 9 фигурок «Украинки» в 6-ти вариантах раскраски. Роспись выполнялась местными мастерами с ЧерниговоСумской земли и в дальнейшем была эталонной для многих других отечественных производств тонкой керамики. Указанная скульптура стала знаковым сборным образом представительниц нашего народа, через которую познавали нашу национальную идентичность в европейском фарфоре и вообще в мире. Лепился артефакт с натуры. Прототипом выступила местная красавица из украинских крепостных с. Волокитного «Палажка». Через 160-170 лет к теме первой увековеченной в отечественном фарфоре «улыбающейся коры» из народа вернулось производство С. Воронова «Alis-K». Реплики и реконструкции исторической «Украинки» были переведены в уменьшенный формат, 22,7 в менее, чем 15 см (так называемая арт-миниатюра). Художниками обозначенного учреждения предложены как рефлексии, так и обновленные варианты росписи, которые перекликаются с парными предметами художественных наборов - декоративными коллекционными наперстками увеличенного размера, оформленными в традициях стилистики Волокитина середины XIX ст. 
ISSN 2410-1176 (Print) Вісник КНУКіМ. Серія Мистецтвознавство. Вип. 39. ISSN 2616-4183 (Online)

Ключевые слова: скульптура малых форм; фарфор; «Украинка»; «Палажка»; «Марина Мнишек»; Волокитино; А. Миклашевский; С. Воронов.

Shkolna Olha, Doctor of Arts, Borys Grinchenko Kyiv University, 18/2 BulvarnoKudriavska St, Kyiv, Ukraine

Reconstruction of the first fine-ceramic sculptural image of «Ukrainka» as a project by S. Voronov's «Miklashevsky historic porcelain factory».

The purpose of the article. The aim of the work is to analyze the sculptural image of "Ukrainka" in the 1850s made at the Volokytyne factory and its "replicas" in the contemporary works of Alis-K company.

The research methodology was based on a set of principles, approaches and methods. The principle of scientific objectivity, culturological and art history analysis and the comparative method were used for drawing historical comparative parallels with the development of porcelain production in the 19th century in Europe; the historical and cultural method allowed for showing the symbolic image of the statuette of "Ukrainka" and its painting; the method of art history analysis was employed for understanding the specifics of shaping and decoration at the Volokytyne porcelain factory and the production of the Alis-K company.

The scientific novelty of the work lies in the introduction into scientific circulation of a comprehensive scientific analysis of the figurative component of «Ukrainka» produced by the Miklashevsky fine ceramics factory and its modern replicas, as well as in attempts to interpret the ideological content of the designated works. Conclusions. The appearance in Ukrainian «white gold» of the sculpture of small forms of «Ukrainka» in national clothes dates back to around 1850. This statuette was made according to the old classical techniques of hand-molding with plastic elements of dolepolving at the Volokytyne porcelain factory.

Nowadays there are 9 figures of "Ukrainka" in 6 variants of coloring. The paint job was made by local craftsmen from Chernihiv and Sumy regions and later became a standard for many other domestic manufactures of fine ceramics. This sculpture became a symbolic composite image of representatives of our people, through which one could learn our national identity in European porcelain and in general in the world. The artifact was molded from life. The prototype was a local beauty, Palazhka, a Ukrainian serf from the village of Volokytyne. 160-170 years later, S. Voronov's "Alis-K" returned to the immortalized theme of the first "chirping bark". Replicas and reconstructions of the historic "Ukrainka" were transformed into a smaller format - 22.7 was made into less than $15 \mathrm{~cm}$ (the so-called art miniature). The artists of the designated institution offered both reflexions and updated versions of the paint job, which echo with the pair objects of art sets decorative collectible thimbles of increased size, decorated in the traditions of the style of Volokitino in the mid-nineteenth century.

Key words: sculpture of small forms; porcelain; Ukrainka, Palazhka; Maryna Mnishek; Volokitino; A. Miklashevsky; S. Voronov.

Вступ. Упродовж 2017-2018 pp. одеським колекціонером i промисловцем С. Вороновим було започатковано унікальний проект. У межах ідеї відтворення на сучасному етапі окремих віх українського тонкокерамічного виробництва - реконструювати найбільш вдалі пластичні досягнення історичного минулого. Зокрема, переосмислити здобутки вітчизняних фарфорових брендів, зупинившись на найвищих мистецьких злетах пройдешніх епох. Першим і надзвичайно сміливим кроком у цьому напрямі було звернення до спадщини відомого заводу А. Міклашевського у Волокитиному на Чернігово-Сумській землі. Це панське виробництво, яке діяло більше двадцяти років (1839-1861рр.), було зорієнтоване на потреби аристократів (Федевич, 2005). Продукція означеного підприємства мала ексклюзивний характер, оскільки споживачами були дуже вибагливі замовники насамперед, дворянські кола етнічних України, Польщі, Росії.

Відповідно, актуальність проблеми окреслюється специфікою проведеного унікального з виробничої та мистецтвознавчої точок зору експерименту, оскільки в Україні нині стрімко втрачається культура «білого золота», напрацьована впродовж останніх 350 -ти pp. У зв’язку з цим варто зазначити, що держава сьогодні не формує культурну політику в 
галузі легкої промисловості, i, відповідно, не в змозі іï реалізовувати. Але силами окремих подвижників і поціновувачів тонкокерамічної справи, що зорієнтовані на кола вітчизняних і закордонних колекціонерів, український національний фарфор поступово починає відроджуватися у новітніх формах розвитку, і екстраполює художньо осмислені образи наших арт-мініатюрних співвітчизниць та мотиви рідної флори в європейський і світовий художній простір артринку.

Проблемі появи образу першої «Українки» у національних строях у вітчизняному фарфорі присвятили увагу кілька дослідників. Упродовж 1936-1957 рр. над спадщиною Волокитиного працював знаний практик тонкокерамічної справи, технолог i мистецтвознавець П. Мусієнко. Він звернув особливу увагу на скульптурку заводу А. Міклашевського у національних строях (Мусієнко, 1959). Надалі першу значущу працю 3 історії розвитку цього виробництва видала 1959 р. знаний історик декоративно-ужиткового мистецтва, промислів і промисловості С. Спаська (Спаська, 1959). Поглиблювали вивчення іï напрацювань музейники Сум Є. Кочерженко 1971 р. та Л. Федевич 2005 р. (Кочерженко, 1971, с. 12).

Уточненням атрибуції волокитинських фігур займалася i знаний дослідник української тонкої кераміки, доктор мистецтвознавства, професор Львівської національної академії мистецтв Ф. Петрякова наприкінці 1980 x - початку 2000-х рр. (Петрякова, 1991). 2010-го р. була видана каталожна праця про Фарфоровий завод А. Міклашевського російським фахівцем з «білого золота» Е. Самецькою. У двотомному виданні було наведено кілька основних видів розфарбування скульптур «Українки» та парного до неї «Козака» без спеціального аналізу цих творів (Самецкая, 2010). У 2013 р. вийшла друком праця за матеріалами додатків докторської дисертації О. Школьної, у якій була приділена значна увага штату художників і скульпторів означеного виробництва (Школьна, 2011). У 2017 р. оприлюднена стаття ще одного київського мистецтвознавця Г. Решетньової, яка розширювала дані попередньо вказаної праці щодо майстрів - авторів розпису (Решетньова, 2017). за рахунок введення до наукового обігу рукопису краєзнавця з Волокитиного М. Жука (Жук, 1964).

Крім вищезгаданих першоджерел, варто згадати праці Т. Арапової з історії розвитку китайської грубої й тонкої кераміки, звідки поширювалося в Європу багато модних тенденцій (Арапова, 2007). та російських художніх силікатів колективу поважних вчених Т. Дулькіної та Н. Ашаріної (Дулькина, 1978), праці Д. Міллер з загальної історії антикваріату (Миллер, 2003) та Р. Пьорселла 3 типології та класифікації колекційної порцеляни та посуду зокрема (Pearsall, 1997). Важливою також в контексті даної теми $\epsilon$ праця 3 семантики i символіка флореальних мотивів легендарного вченого М. Золотницького, перевидана 1992 р. (Золотницький, 1992). Але в жодному з означених видань ніколи не розглядалося окремо взяте питання походження «Українки», іiі прототипів, символічно-образного навантаження твору, його основної ідеї тощо.

Метою дослідження $\epsilon$ прослідковування етапів звернення у вітчизняному «білому золоті» до образу красунь 3 народу в національному вбранні, та характеристика їх художніх особливостей відповідно до естетичних стереотипів виробників i запитів споживачів упродовж середини XIX ст. - 2010 х рр.

Об'єктом дослідження є традиції вітчизняного фарфору середини XIX -початку XXI ст., предметом - скульптура «Українки» у національному одязі як віддзеркалення у тонкій кераміці культурної ідентичності українців з часу її самоусвідомлення і до сьогодення.

С. Воронов у своєму першому проекті реконструйованих творів минулого в рамках започаткованої ним серії «Історичний фарфор» звернувся разом із групою провідних вітчизняних художників до образу відомої «Українки» заводу А. Міклашевського. Ідея полягала у створенні сучасних реплік цієї статуетки як з майже дослівним цитуванням, так і 3 новітніми різновидами декору, протиставленні розуміння колишніх естетичних вимог i сьогодення. Причому для цього персонажу, виконаного, взоруючись на історичний першовзірець, були розроблені спеціальні сувеніри - серія арт-мініатюрних наперстків, пластично і художньо вирішених в стилі Волокитиного доби його найвищого розквіту. 
Зважаючи на те, що названий твір є найбільш раннім відомим нам зображенням українки у народному одязі, експеримент полягав у демонстрації з одного боку традицій вітчизняного високого фарфору, а з іншого - трансформацій у ньому впродовж останніх 160 170-ти рр. Відтворення здійснювалося на базі Національного музею українського народного декоративного мистецтва, колектив якого на чолі з директором Л. Строковою люб'язно надав оригінал з фондів збірки для зняття моделі з метою ії відлиття у фарфорі.

3 оригінальної статуетки заввишки 22,7 см скульптором Андрієм Стельмахом на замовлення С. Воронова було виконано відливок, який ліг в основу оновленого на сучасному етапі знаменитого образу «Українки». За задумом автора ідеї проекту виготовлена мініатюрна модель мала не дослівно цитувати відомий першовзірець, а бути реплікою унікального за своєю значимістю для історії вітчизняного та й загалом європейського мистецтва твору. I якщо історичний прототип мав свою пару у вигляді чоловічої фігури, то виготовлення реконструйованого артефакту супроводжували інші предмети. Зокрема, артмініатюрні сервізні групи роботи відомої художниці О. Жернової з розписами в стилі заводу А. Міклашевського та пластично промодельовані наперстки в розписі інших кількох авторів, виготовлені 3 рельєфними та живописними елементами, взорованими на автентичні волокитинські.

Аби краще зрозуміти сенс нововведень та їх трансформаційного осмислення, варто зупинитися на початкових розробках означеного підприємства.

Так, фарфоровий завод А. Міклашевського у с. Волокитиному на Чернігово-Сумській землі діяв протягом 1839-1861 рр. (доба історизму, романтизму і реалізму в мистецтві). Фарфорову справу Волокитиного багато в чому визначають скульптурні вироби підприємства, а власне візитівкою, певним «знаком якості» досягнень виробництва є фігурка «Українки». А. Міклашевський як поміщик-заводовласник був оперативним, яскраво відчував кон'юнктурну лінію в розвитку декоративного мистецтва свого часу, знав запотребовані напрямки розвитку фарфору та вмів співвідносити їх зі смаками тогочасних споживачів тонкої кераміки (еліти суспільства).

У цілому у волокитинських виробах чітко відображилися впливи модних віянь у розвитку твердого фарфору Франції та Австрії поч. XIX ст., захоплення екзотикою (декоративністю народного вбрання), за аналогією 3 яскравим східним мистецтвом, стилізацією природних форм, манірністю - відтворенням звивистих ліній. Аналізуючи напрацювання фабрики за ії нетривалий період 22-х-річного існування, важливо відзначити, що серед асортименту скульптур заводу А. Міклашевського найбільш знаковими й нетривіальними досі лишаються парні образи «Українки» в національних строях та «Козака».

Саме Фарфоровий завод А. Міклашевського протягом 1840-1850-х рр. був єдиним на Україні виробником фарфорової пластики, на той час дуже популярної на великих приватних підприємствах, приміром, гарднерівського, або Попова, потому й інших заводів і нескінчених дрібних майстерень. В етнічній Україні був обраний шлях поєднання соковитого пластичного моделювання ніби 3 «надлишком», похідного від традицій французької та австро-німецької скульптури малих форм, і виразності народних розписів 3 мажорним колоритом.

«Фасонів» скульптури Волокитинського заводу, вочевидь, було не менше двохста, оскільки кількість різноманітних композиційних рішень, відомих за експонатами окремих колекцій та публікацій, перевищує 180 найменувань. Окрім дрібної пластики, до цієї групи увійшли: фігурний посуд (кухлі, глечики, маснички) та чорнильниці. у цілому скульптурні образи є досить різноманітними. Це сюжети та композиції як власне волокитинські, так i ті, що були репліками до знайдених рішень популярних героїв з інших виробництв.

Над асортиментом скульптурок протягом діяльності підприємства працювали різні майстри. Крім «екзотів» китайців і китаянок, оголених одалісок, що пізніше стали мегапопулярними у добу модерну й ар деко, А. Міклашевський випускав фігурки національних героїв Франції та Англії, вельмож та аристократів під час аудієнцій, милих дітлахів, красунь, що читають, пасторальні й галантні сцени, образи Спасителя, жанрову 
скульптуру кшталту образів представників різних верств населення за притаманними їм заняттями - полюванням, збирацтвом винограду, плетенням взуття тощо.

Невелика кількість з фігурок Волокитиного, що певною мірою тяжіє до реалістичного відтворення дійсності, датується серединою XIX ст., часом оновлення пластичної мови виробництва й поступовою відмовою від другого рококо. Визнаною перлиною всього волокитинського фарфору вважається статуетка «Українка», персонаж 3 місцевого середовища. Це фігурка дівчини, яка одягнена в український національний одяг, з віночком на голові, що тримає квітку в лівій руці (молитовна захисна композиція). Статуетка має низьку прямокутну основу-подіум, за спиною дівчини юного віку знаходиться великий кошик для квітів на рокайльній ніжці з верхом у вигляді глибокої мушлі. Враховуючи цю специфіку композиції, виріб нерідко називають сільничкою чи попільничкою.

За переказами місцевого населення зображення «Українки» ліпилося 3 натури. Прообразом стала місцева красуня з селян-кріпаків А. Міклашевського на ймення Палажка. Мешканці Волокитиного надалі впізнавали у готовому виробі прототип, тому за фігуркою міцно закріпилася однойменна назва. Ідея фабрикації, імовірно, належала керівнику підприємства, який змінив Франца д’Арта та фінського уродженця Антипича, місцевому мешканцю Федору Петруніну (Петруні). Розробкою моделі займався, мабуть, єдиний модельник виробництва Семен Антонов. Висота відомих відливків скульптури коливається у межах 22,6-22,7 см, що на 10-15\% менше, ніж іï початковий розмір (фарфор у випалі дає усадку). Тобто вихідний розмір речі сягав 25 см.

Характерна особливість «Українки» в тому, що образне рішення засноване на виразності національного костюму, специфічного комплексу одягу дівчини ЦентральноПівнічної України. Статуетка відома у 9 екземплярах, які тотожні конструкцією, концепцією розробки декору й навіть неточностями передачі пропорцій тіла (постава дівчини має дещо укорочені ніжки, які замиловують своїм дещо наївним виконанням).

Різняться фігурки за колірним вирішенням компонентів одягу, хоча при поліхромному розпису корпусу використані фактично одні й ті самі кольори: шарлатовий (в червонуватому та жовтому відтінках), густий синій, жовтий, бузковий, чорний, рідше зеленкуватий (салатовий), зелений, блакитний, рожевий. Інакше кажучи, колорит розпису статуеток виразно окреслюється межами звичайної палітри фарб Волокитинського заводу. Завдяки відчуттю міри, такту в використанні кольорів, у передачі краси народного одягу, розписи фігурок етнографічно достовірні та декоративні.

Зазвичай, автором розпису барвистого одягу скульптури малих форм Волокитиного був кращий художник по «фігурній частині» П. Алексєєв. За його проектами статуетки української тематики розписували живописці Ю. Борисов, І. Корнейчуков, Костянтин, Спиридон, I. Мейстер, брати Мосакови, С. Шувалов. Пластичний і живописний декор на підприємстві також виконували місцеві художники Андрій Качура, Калмиков, Анна Саржан, Анастасія Косолап, Тихон Смик та його син Григорій, Василина Козьол та ін. Судячи 3 характеру інваріантного розпису фігурки «Українка», майстри-живописці, які його розробляли, напевно не походили з теренів етнічної Росії (оскільки відомо, що деякі майстри Волокитиного походили з підмосковних маєтків князя), і відчували специфіку місцевого колориту, етнокультурну своєрідність строїв різних регіонів.

Нині можна із впевненістю відзначити, що колективу означених фахівців було притаманне розуміння культури високого фарфору, знання основ композиції «білого золота», відчуття узгодженості кольорів, суті поєднання елементів українського народного строю, етнокультурних особливостей специфіки носіння традиційного одягу окремих регіонів України. Не до кінця вивірене співвіднесення пропорцій, специфічну недомодельованість обличчя «Палажки», що сповіщає портретованій рис миловидної «няшки», видає певну наївність портретованої, що віддалено нагадує усміхнену архаїчну кору.

Принагідно варто зауважити, що ця аналогія виводить окреслену скульптуру до відомих символічних образів світового фарфору, в яких підкреслюється національна ідентичність героїв. Приміром, китаянок 3 віялом, індійських махарадж, іспанських 
танцівниць, француженки Жанни д’Арк, німецьких пастухів і пастушок тощо. Можна зазначити, що асоціативний ряд 3 «архаїчною корою» в даному випадку $є$ абсолютно свідомим натяком саме на грецьку генезу символічної складової образу, що уособлює вічно молоду осміхнену дівчину, ніжне створіння, народжене для божественної посвяти i служінню прекрасному, без зайвих нашарувань смислів.

Зазвичай, такі історичні прототипи мали або вотивну (жертвенну), або меморіальну (увічнення) функцію, цебто слугували подарунком заможних донаторів вищим істотам, що мали божественне походження. При цьому поза «Українки» суттєво нагадує поставу античної кори - статична фігура з піднятою рукою, що тримає квітку (молитовна захисна позиція). Красномовною $є$ і поліхромія, в якій основні акценти приділено розфарбуванню плахти, що захищає лоно жінки, де вона має виношувати малюків. Тому і у прадавніх кор і в означеному персонажі Волокитиного одяг від пояса традиційно має яскравий барвистий візерунок оберегового призначення.

Частково символіка одягу античних кор відображена в композиційному i декоративному вирішенні «Українки». Вочевидь, майстри періоду становлення вітчизняної фарфорової пластики у національних строях вважали важливим підкреслити саме одухотвореність, навіть деяку наївну безпосередність збірного образу нашого населення, провести аналогію між високою класикою на зорі зародження образних характеристик прадавніх греків, що заселяли наші північнопричорноморські терени 3 давніх давен, і стали підгрунтям, проклали місток до культури XIX ст., доби, коли Україна виборювала своє право на ідентичність у межах імперських зазіхань, нівелюючих автентичні риси місцевого люду.

Враховуючи, що античні кори часто ставали каріатидами, як в Афінському акрополі, святая святих колиски світового мистецтва - Греції, вони несли непосильну ношу архітектурних споруд на своїх плечах, стаючи окрасою чиїхось маєтків або окремих будівель. Вірогідно, автор задуму добре розумівся на античній міфології, і через цей знаковий образ у революційну добу Т. Шевченка, - добу піднесення національної самосвідомості, намагався донести власне бачення сутності українського народу, для якого були притаманні зовнішня привабливість (українки й досі самі жадані наречені в світі), лагідність характеру і певна «одигітріальність» - указування шляху до божественної істини, замилованість у все прекрасне, в оточуючий світ, природу, з якою наші пращури мали тісні взаємини на свідомому і підсвідомому рівнях.

На додачу варто зазначити, що кори передрікали можливість загибелі цивілізацій, тому скульптор намагався попередити оточуючих про необхідність збереження милих оку тендітних красунь, що потребують захисту (рис.1).
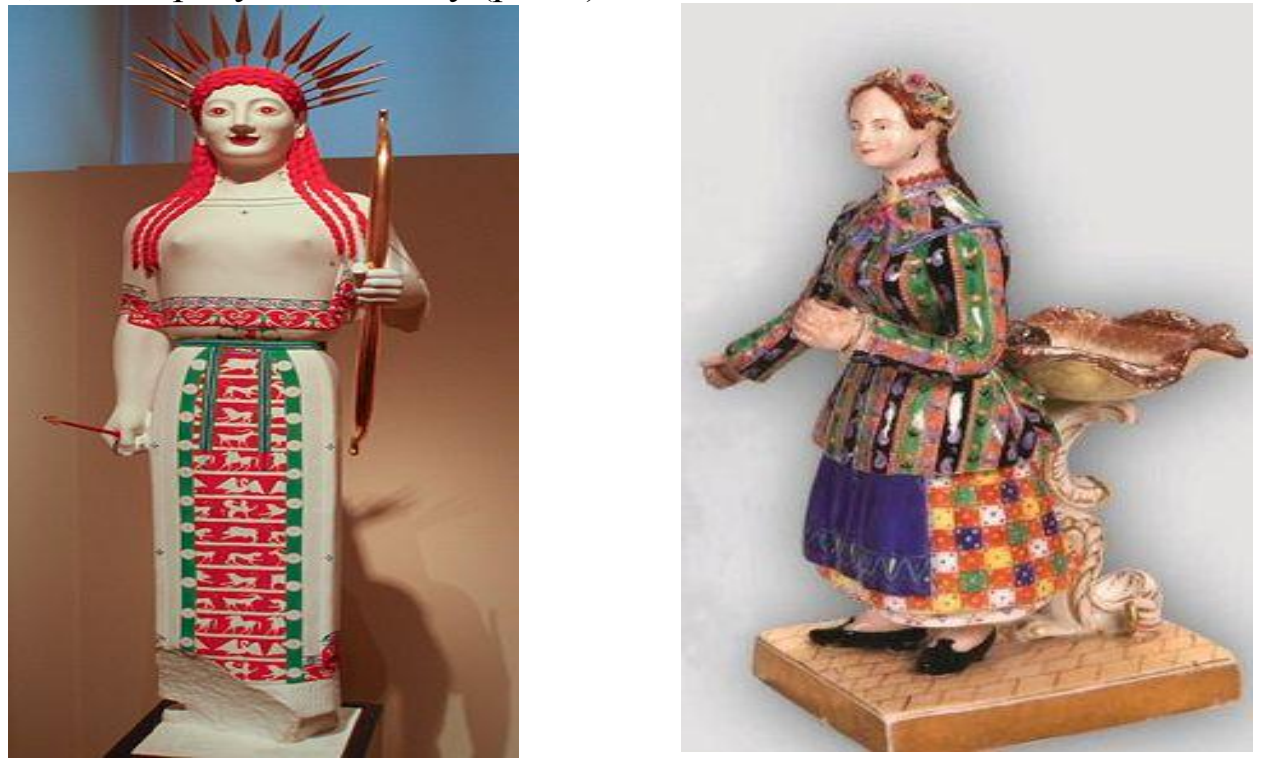

Рисунок 1. Реконструкція давньогрецької кори в пеплосі і «Українка» заводу А. Міклашевського Figure 1. Reconstruction of Ancient Greek Bark in Peplos and «Ukrainka» at A. Miklashevsky Plant 
Парною статуеткою до «Українки» $є$ скульптура «Козак на посту». Інакше його називають «Мисливець», «Козак зі зброєю», «Уральський козак» (відомі екземпляри в середньому мають заввишки від 23,5 до 24,1 см). Це зображення бородатого чоловіка у довгому жупані та шапці кшталту смушкової. Цей герой зображений з круглою порохівницею та кинджалом біля поясу, правою рукою він тримає цівку вертикально стоячої зброї (рис. 2).

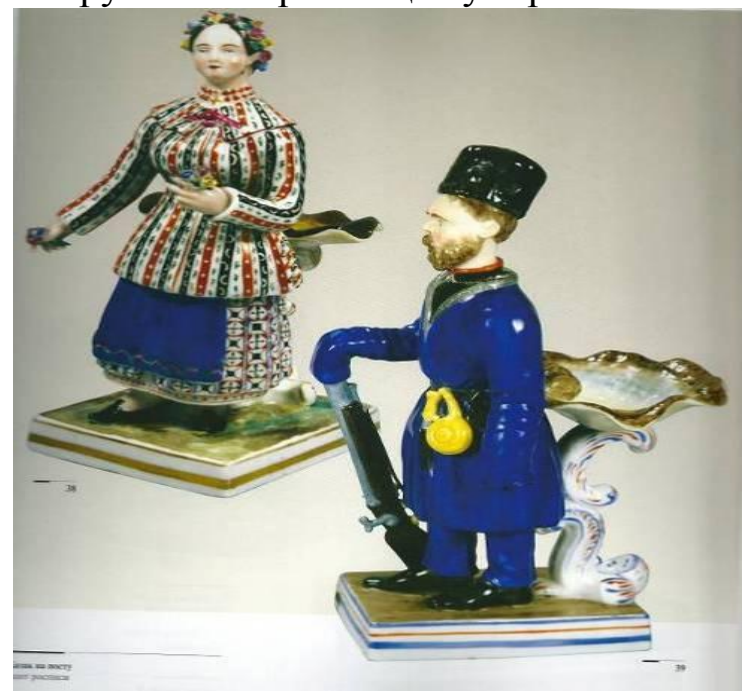

Рисунок 2. Фарфоровий завод А. Міклашевського. Скульптура «Українка» та «Козак на посту». Варіант розпису.

Figure 2. A.Miklashevski's porcelain factory. A sculpture «Ukrainian» and «Kozak on a post». A variant of a picturesque decor.

Фігурка стоїть у центрі низького прямокутного цоколя, злегка притулена до мушлі на рокайльній ніжці. Композиція не замкнена та при круговому огляді дозволяє відчути художню виразність круглої скульптури 3 різних ракурсів. Усі екземпляри «Козака зі зброєю» вирішені стримано (рис. 3), розписані у локальні кольори, при чому основна увага приділялася тонуванню жупану (в червоний, волошковий, темно-зелений барви).

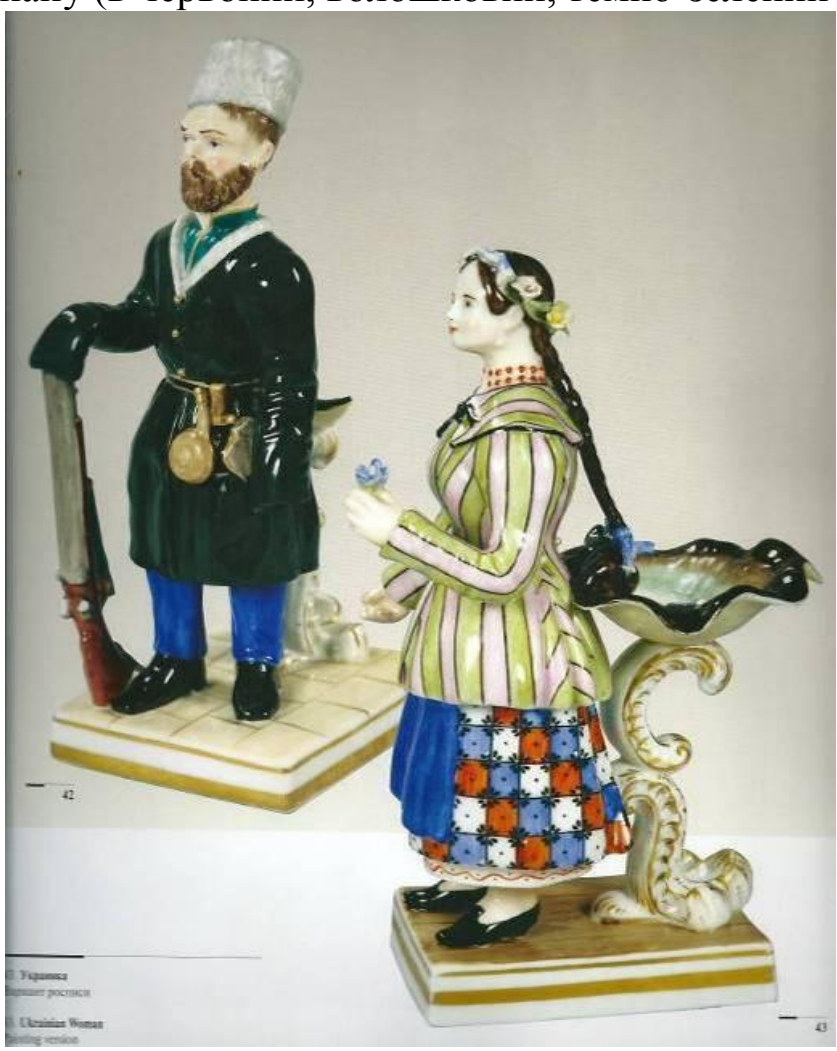

Рисунок 3. Фарфоровий завод А. Міклашевського. Скульптура «Українка» та «Козак на посту». Варіант розпису.

Figure 3. A.Miklashevski's porcelain factory. A sculpture «Ukrainian» and «Kozak on a post». A variant of a picturesque decor. 
За переказами праонука головного інженера підприємства А. Гутмана, образи козака та українки ліплені з місцевих жителів Волокитиного, з натури. Але сюжет початково було присвячено зустрічі Марини Мнішек та Лжедмитрія біля фонтану. Нібито тому парний до українки козак одягнений не в національний стрій. За аналогіями у стилістиці оформлення та пластичного моделювання інших скульптур Волокитинського фарфорового заводу випливає, що всі варіанти фігурок козака та українки датуються 1850-ми рр. Серед відомих зображень парних статуеток з українських державних і приватних колекцій кращими $є 6$ варіантів розпису. При уважному розгляді фіксується не лише різне трактування одягу портретованих, а й неоднакові способи вирішення пластичного моделювання уквітчання віночку, коси та жестів рук «Українки» (рис. 4).

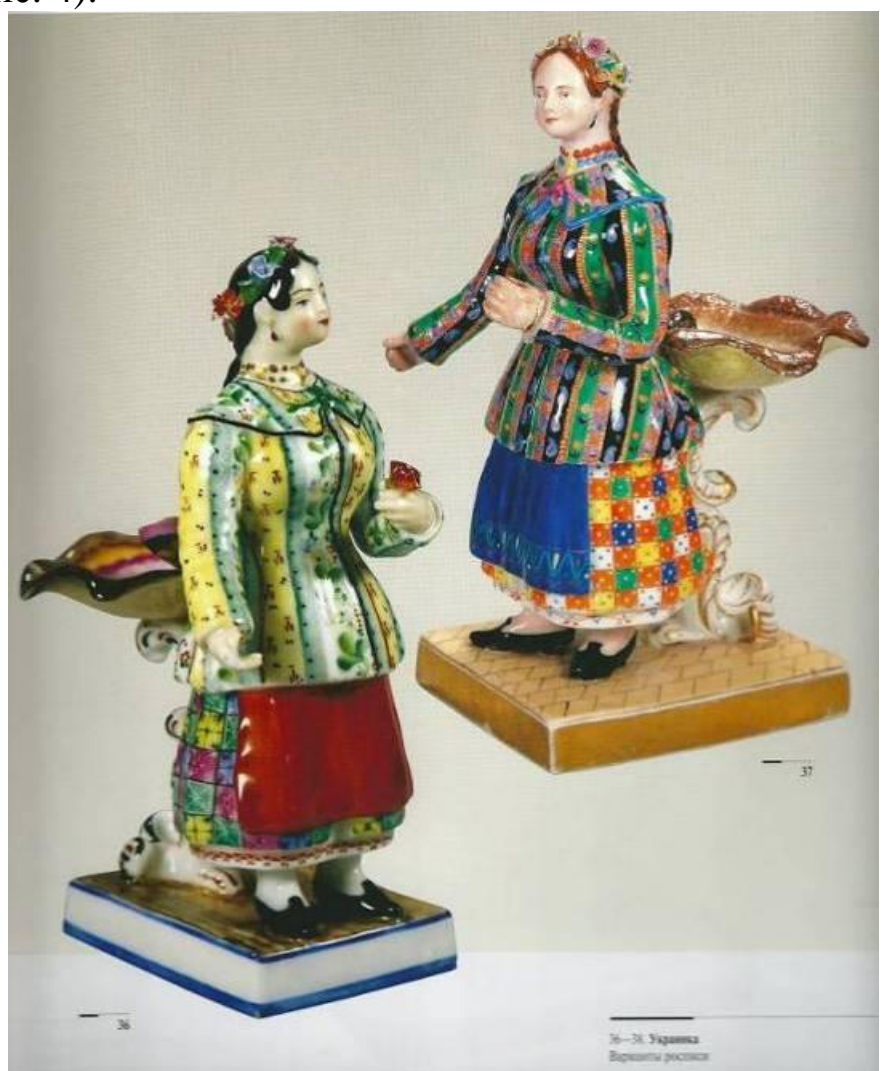

Рисунок 4. Фарфоровий завод А. Міклашевського. Скульптури «Українка». Варіант розпису.

Figure 4. A.Miklashevski's porcelain factory. A sculptures «Ukrainian». A variant of a picturesque decor.

При цьому композиційно одяг деяких «Українок» вирішений подібно, різниться лише колірна гама, застосована художником. Можна зробити припущення, що деякі фігурки розписував один і той самий майстер (рис. 5). Так, розфарбування верхньої скульптури 3 рисунку 4 та декоративне вирішення одягу моделі на рисунку 5 відчутно подібне. 


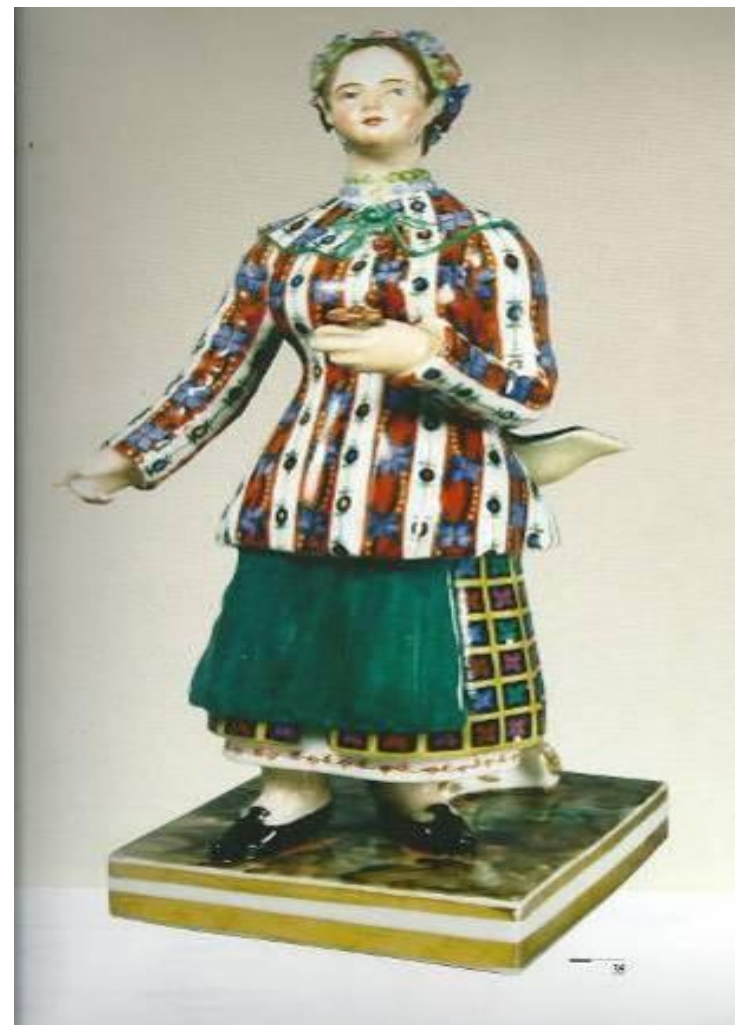

Рисунок 5. Фарфоровий завод А. Міклашевського. Скульптура «Українка». Варіант розпису.

Figure 5. A.Miklashevski's porcelain factory. A sculpture «Ukrainian». A variant of a picturesque decor. Деякі моделі (рис. 6) усміхнені, дещо вигнуті назад.

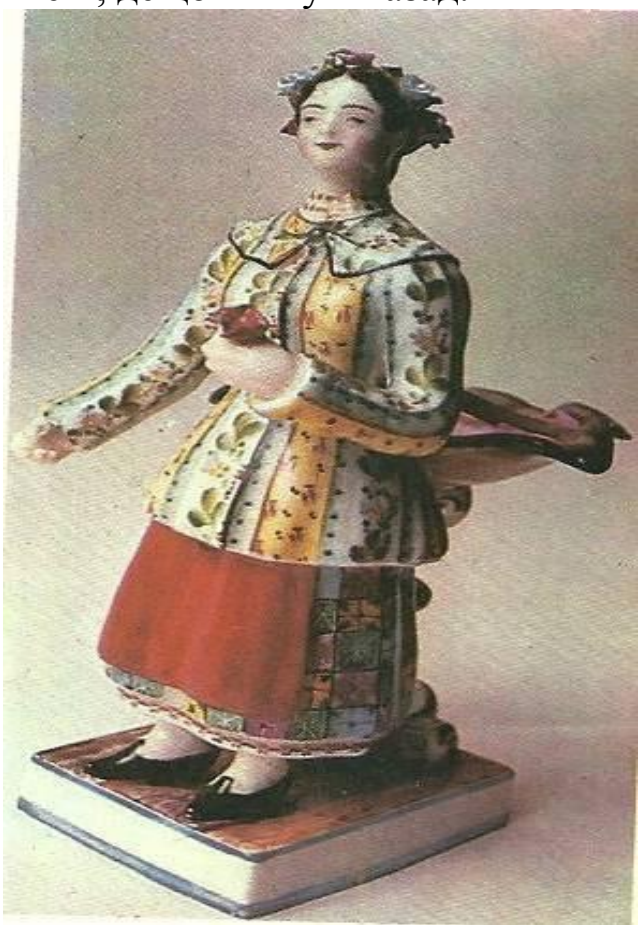

Рисунок 6. Фарфоровий завод А. Міклашевського. Скульптура «Українка». Варіант розпису.

Figure 6. A.Miklashevski's porcelain factory. A sculpture «Ukrainian». A variant of a picturesque decor.

В інших відчутна зосередженість на внутрішньому стані (рис. 7), інтровертний погляд «всередину». 
ISSN 2410-1176 (Print) Вісник КНУКіМ. Серія Мистецтвознавство. Вип. 39. ISSN 2616-4183 (Online)

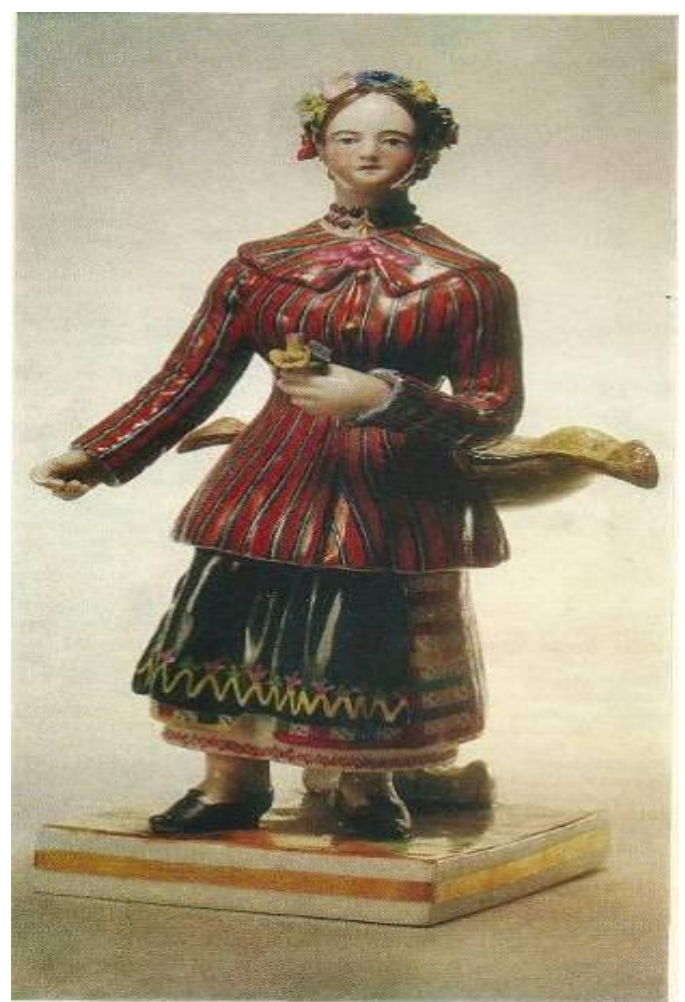

Рисунок 7. Фарфоровий завод А. Міклашевського. Скульптура «Українка». Варіант розпису.

Figure 7. A.Miklashevski’s porcelain factory. A sculpture «Ukrainian». A variant of a picturesque décor.

Суттєво різниться не тільки розфарбування одягу «Палажки», а й подіуму, на якому вона стоїть, що свідчить про можливі вияви почерку різних волокитинських митців (рис. 8).

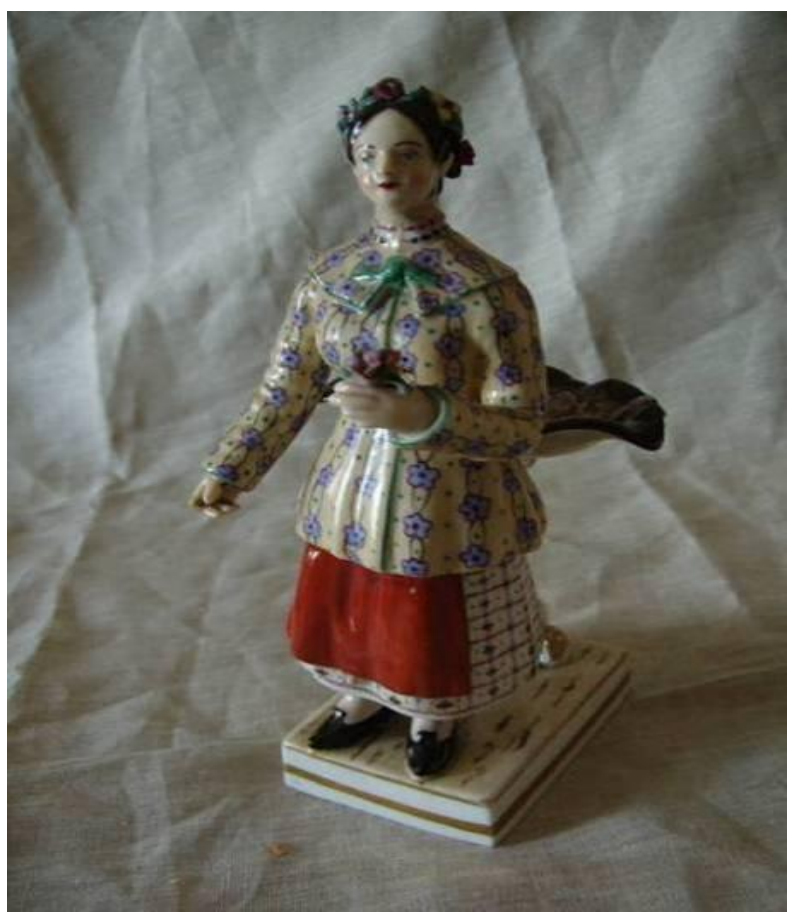

Рисунок 8. Фарфоровий завод А. Міклашевського. Скульптура «Українка». Варіант розпису.

Figure 8. A.Miklashevski’s porcelain factory. A sculpture «Ukrainian». A variant of a picturesque décor.

В експерименті фірми «Alis- ${ }^{\circ}$ » сучасні митці спочатку намагались відтворити традиційні волокитинські взірці (рис. 9), апелюючи до різновидів декору моделі XIX століття (рис. 10). Проте, «Українка» XXI століття (рис. 11) - це доповнення до колекційного наперстку, і тому їй відведено дещо іншу роль. Ніж у першовзірці. 


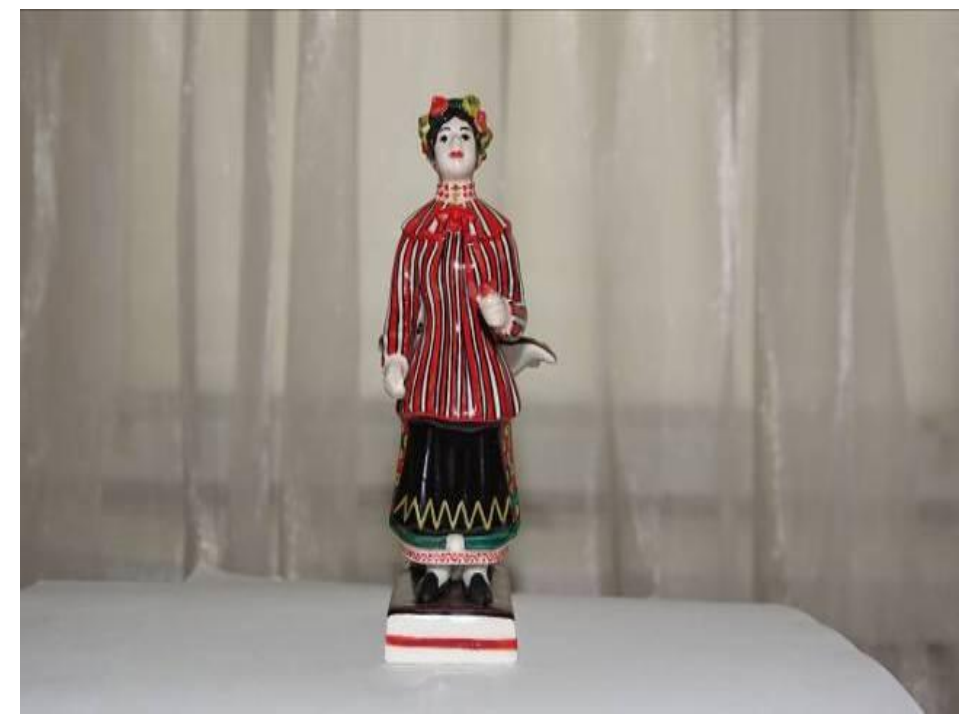

Рисунок 9. Репліка «Українки» заводу А. Міклашевського. 2018. Розпис фірми «Alis-К»». Figure 9. Remark of «Ukrainian» of factory A.Miklashevskogo. 2018. Painting of firm «Alis- $\mathrm{K}^{\circ} »$.

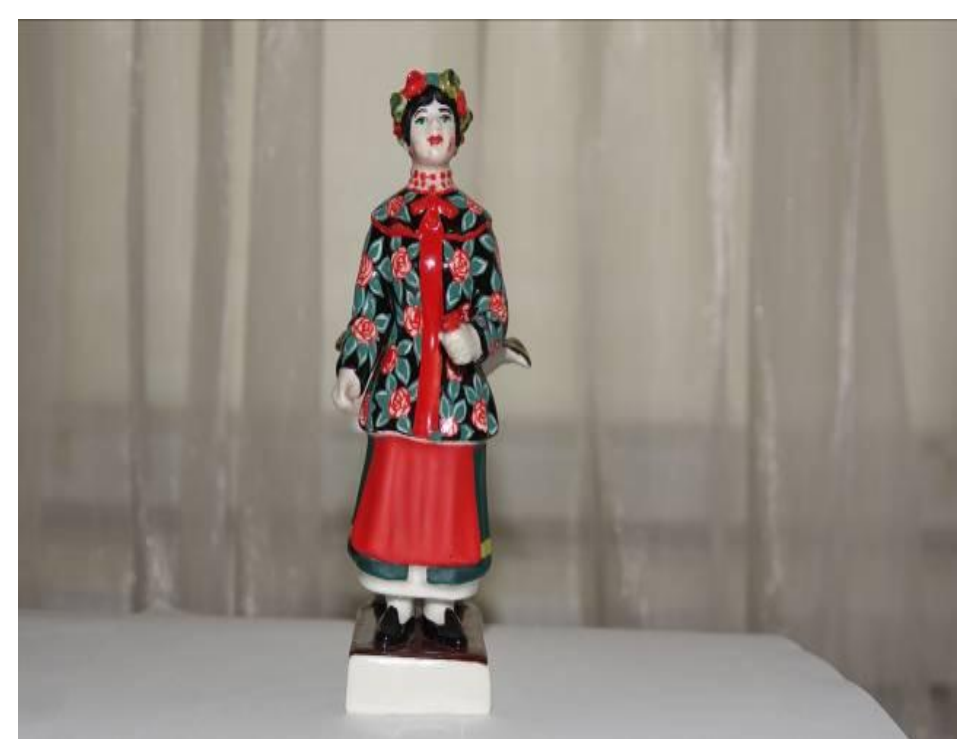

Рисунок 10. Репліка «Українки» заводу А. Міклашевського. 2018. Розпис фірми «Alis- $\mathrm{K}^{\circ} »$.

Figure 10. Remark of «Ukrainian» of factory A.Miklashevskogo. 2018. Painting of firm «Alis- $\mathrm{K}^{\circ} »$.

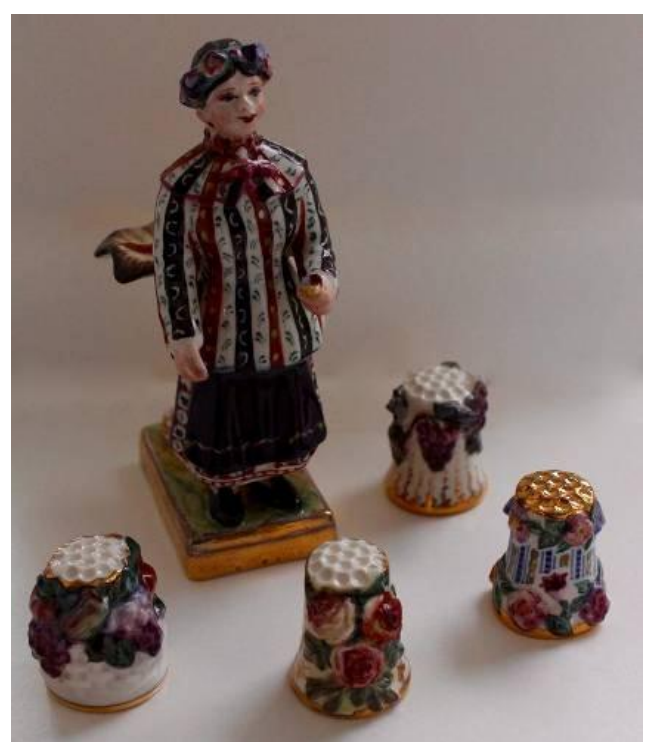

Рисунок 11. Репліка «Українки» заводу А. Міклашевського. 2018. Розпис фірми «Alis-K॰ ». Figure 11. Remark of «Ukrainian» of factory A.Miklashevskogo. 2018. Painting of firm «Alis- $\mathrm{K}^{\circ} »$. 
В ансамблях подарункових виробів від фірми С. Воронова «Alis- $\mathrm{K}^{\circ} »$ «країнка» - це привід згадати автентичні унікальні першовзірці, а головним новітнім предметом, виконаним у стилістиці справдешнього Волокитиного, є саме наперсток (Рис. 12), що виконує оберегову функцію. Це основний предмет випуску, якого «супроводжує» принадна панянка у національних строях.

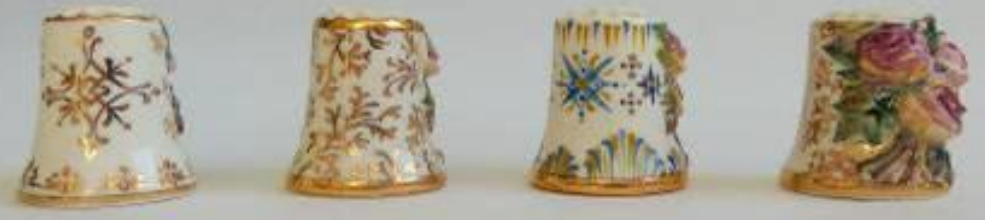

Рисунок 12. Наперстки стандартної форми у розписі керамічними фарбами й золотом, а також із пластичним моделюванням. Варіанти розробок фірми «Alis-K». 2018.

Figure 12. Thimbles of the standard form in a list ceramic paints and gold, and also with plastic modelling. Variants of workings out of firm «Alis- $\mathrm{K}^{\circ} » .2018$.

Враховуючи, що парні постаті українки в національних строях та козака є найпершою у вітчизняному фарфорі вдалою спробою зображення особистостей з народу, їм притаманні риси національної ідентичності, раніше не представлені в українській тонкій кераміці. Саме тому в 2015 р. одеський колекціонер і виробник Сергій Воронов вирішив повернутися до цієї знакової теми в розвитку українського високого фарфору i виготовити серію реплік «Українки» в парі 3 колекційним наперстком в стилі зрілого Волокитиного, а також мініатюрною копією предметів чайного сервізу кшталту «тет-а-тет» (сніданковий набір для інтимного простору) з розписом (рис. 13) а-ля «Волокитинський палісадник квітів» (чайник, цукорниця, блюдо-таця, 2 пари чашок з блюдцями, 10 наперстків).

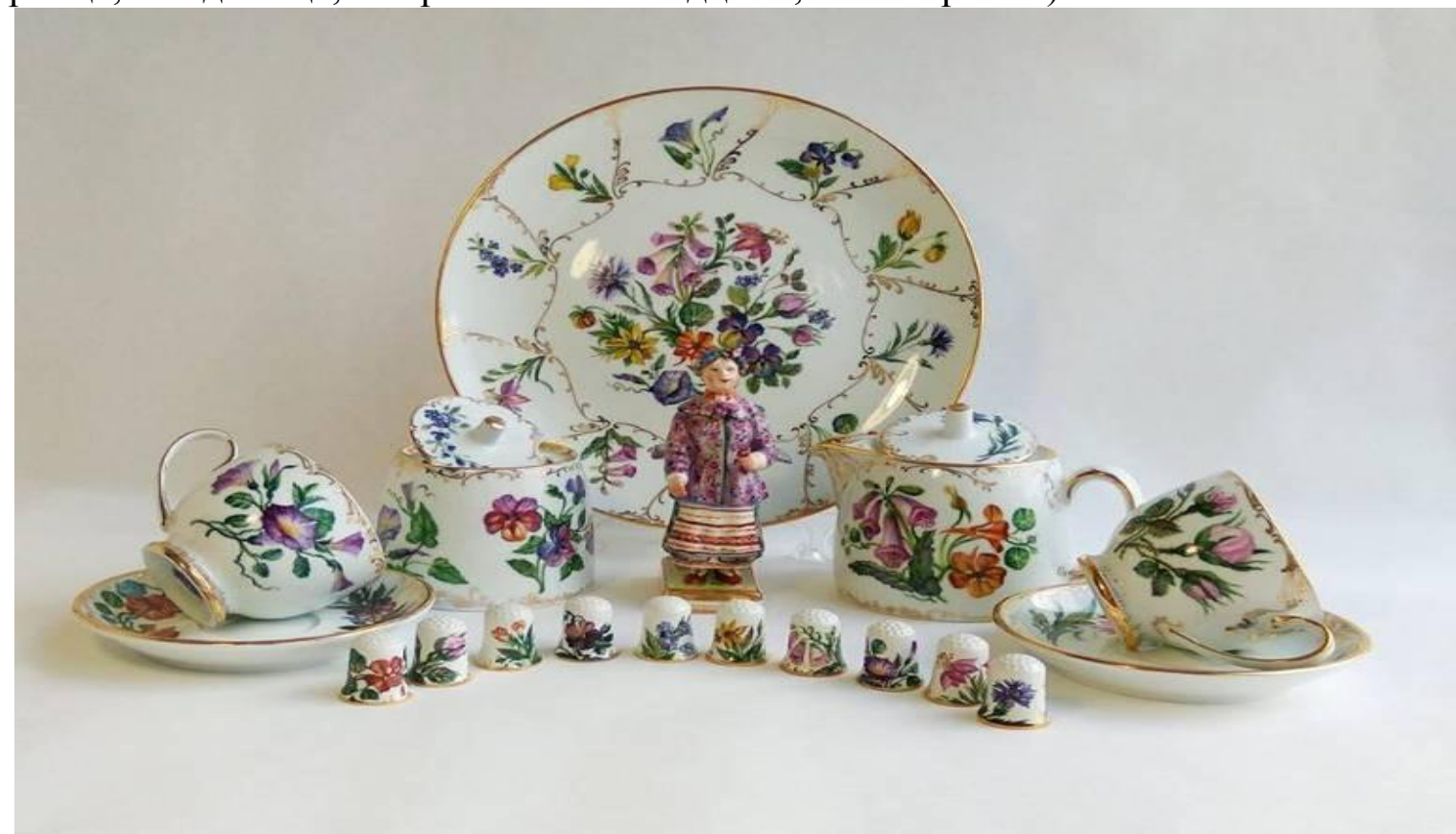

Рисунок 13. Реконструкція «Українки» заводу А. Міклашевського. 2018. Розпис фірми «Alis-K».

Figure 13. Reconstruction of «Ukrainian» of factory A.Miklashevskogo. 2018. Painting of firm «Alis- $\mathrm{K}^{\circ} »$. 
При цьому живописний декор предметів сервізу виконаний в єдиному композиційностильовому річищі і $є$ вдало припасованим до класичної за різновидом й розмірами форми. Його розпис виконувався за дотримання всіх вимог технології класичного фарфору (специфіка нанесення надглазурного фарбового мазка). Інтерпретація квітів опрацьовувалася О. Жерновою 3 опертям на історичний сервіз, що має підсилювати враження від застосування знайдених мотивів й у комплекті з 10 наперстків. По відношенню до останніх розмір скульптури архетипічної «Українки» обирався дещо перебільшеним задля підкреслення переваг символічного значення предмету над його функціональнім призначенням.

4 різновиди скульптурного сюжету апелюють до вічної символіки. Так, виноградна лоза $є$ символом Ісуса Христа та його самопожертви в ім'я людства, троянда - усталений символ Богородиці, гірлянда - розглядається в аспекті символіки родинного зв'язку, кошик символ плодючості та добробуту. Ці вічні мотиви були впізнавані й важливі для людей середини XIX ст. (рис. 14).

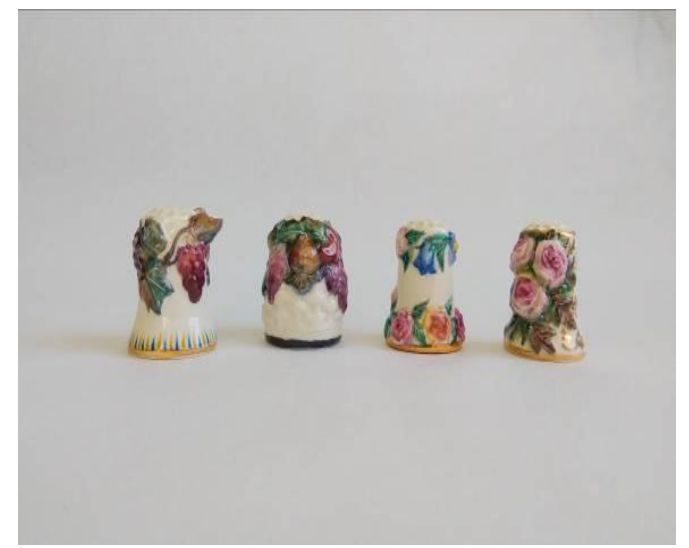

Рисунок 14. Наперстки в розписі керамічними фарбами і золотом, а також із пластичним моделюванням. Варіанти розробок фірми «Alis-K». 2018.

Figure 14. Thimbles in a list of ceramic paints and gold, and also with plastic modelling. Variants of workings out of firm «Alis- $\mathrm{K}^{\circ} » .2018$.

Так, за відомим знавцем флореальної символіки Н. Золотницьким, троянді надається велике значення як цар-квітці. Приміром, за Талмудом червона троянда виросла 3 безневинно пролитої крові Авеля й тому має слугувати окрасою кожної єврейської нареченої у день весілля. У стародавніх греків вінками троянд, переповитих миртом, також прикрашали наречених, пелюстками троянди пересипалось і шлюбне ложе. Вінками з троянд у греків увінчували чоло богів. Загалом білі й червоні троянди у Греції були ознакою жерчеської касти. Натомість у Римі - символом чуттєвого плотського кохання.

За християнським вченням архангел Гавриїл плів для Богородиці три вінки з троянд. 3 білих - ii радість, червоних - страждання, жовтих - iі славу. Тому часто, починаючи 3 давньогерманського живопису, в Європі живописці традиційно зображували Богоматір 3 Немовлям в оточенні трьох вінків троянд згаданих кольорів. Ця традиція дожила у католицькій іконографії до сьогодення, зокрема, як символ доброчесності пап, низки святих тощо. 3 крапель крові біля Розп'яття Спасителя також виросли троянди на моху, так звані мохові, яскравого кольору. Оскільки до Середньовіччя троянда міцно увійшла в світоглядні уявлення Свропи, у Франції кожна наречена мала виходити заміж у доброчесному вінку 3 троянд під назвою «шапель», які плели професійні шапельє (звідси походить відома назва Сен-Шапель).

3 XV ст. у Франції з'явились зображення Богоматері, що простягає квітку троянди своєму Немовляті. 3 цього часу вважалося, що троянда виганяє злих духів і викриває чаклунів. 3 XVI ст. троянда слугувала ще й відмінною рисою християн від євреїв, для чого перші носили іiі на грудях. Я відомо, Андрій Міклашевський, засновник Волокитинського фарфорового заводу, був особливо пристрасним поціновувачем французького мистецтва. По 
кілька місяців на рік він мешкав у Ніцці, замиловувався традиціями французького рококо, пов'язаного із віком галантних відносин.

Тому частина символічного контексту тонкокерамічних творів виробництва у Волокитиному, від троянд (додатково - символ доброчесного лицарства і підтвердження взаємності кохання від дами серця) до кошиків були ще й взоровані на модні артефакти Південної, Західної й Центральної Свропи (Італії, Франції, Німеччини, Австрії). Відповідно, стилістика виробів фабрики А. Міклашевського завжди вирізнялася ще й високою культурою розуміння призначення кожної речі, іiі аури, що формує атмосферу помешкання людини. Але варто відзначити, що українська традиційна культура завжди була обгрунтована, насамперед, релігійною доброчесністю, скерованою на підтримку сімейності, де задоволення відходили на другий план.

За допомоги колективу музейників НМУНДМ (особлива подяка директору Л. Строковій, заступнику директора з науки Л. Білоус, головному зберігачу О. Срмак), модель знімалася професійним скульптором з оригінального експонату, що зберігається в колекції музею. Пластичний і живописний декор для реконструйованих у такий спосіб предметів розробляли за автентичними першоджерелами розпису i скульптурного оздоблення порцеляни заводу А. Міклашевського (рис. 15). Авторами форм і ескізів стали відомі художники фарфору нашого часу - Олена Жернова, Анастасія Медвєдкова-Панчук, Людмила Райковська (колишні провідні й головні художниці Одеського художнього училища, Довбиського фарфорового, Кам’янобрідського фаянсового заводів).

Рисунок 15. Наперстки в розписі керамічними фарбами і золотом, а також із пластичним моделюванням. Варіанти розробок фірми «Alis- $\mathrm{K}^{\circ} » .2018$.

Figure 15. Thimbles in list of a ceramic paints and gold, and also with plastic modelling. Variants of workings out of firm «Alis-K॰ ${ }^{\circ} .2018$.

Приміром, 10 видів автохтонних квіткових декорів Волокитиного знайшли втілення в творчому експерименті Олени Жернової в розписі наперстка, скульптури «Українка», чайного сервізу (червень 2017 р.). 1-й варіант в реконструкції був точною копією автентичного виробу, а надалі автор експериментувала 3 власними творчими ідеями. Приміром, брався мотив бутону троянди і опрацьовувався таким чином, щоб вона відрізнялася від турецької, англійської, перської троянди.

Підкреслювали ідею кохання в творчій інтерпретації О. Жернової сонм з 10 мотивів квітів: тигрова лілея під девізом «Твоя гордість змушує мене страждати», березки «Обіцяю тобі райську насолоду», ротики «Потребую твоєї прихильності», волошка «Довірся мені», настурція «Я не відступлюся», братки (Анютині вічка) «Думаю про тебе постійно», жоржина (далія) «Розставання буде болісним для мене», незабудка «Пам'ятай про мене», бутон троянди «Готовий чекати нескінченно», наперстянка «Готовий на будь-які жертви заради кохання».

Крім звичайної форми колекції наперстків С. Воронова під №1 (виробництва Довбиського фарфорового заводу), для проекту його підприємства «Alis-K» (Одеса) 
«Меморіальна реконструкція шедеврів українського історичного фарфору в сучасній артмініатюрі» 23 квітня 2018 р. презентованого у Національному музеї українського народного декоративного мистецтва, було розроблено кілька нових форм скульптурно промодельованих наперстків. Їх виконували вищеозначені майстри, які не мали змоги бачити працю своїх колег у процесі творчої роботи. Розпис тривав на 4-х різновидах дизайнерських форм скульптурних наперстків під умовними назвами «Кошик з фруктами», «Виноградна лоза», «Букет троянд» (на зворотному боці 3 геральдичними мотивами) та «Квіткова гірлянда» 3 дзвіночками. Це відповідно - символи добробуту, божественної суті, кохання та поліморфних побажань, зберігаючи які в помешканні у відповідних зонах фен-шуй, можна поліпшити недомодельовані сегменти життєвої сфери.

Загалом, за відливком 3 оригінальної моделі був виготовлений один різновид скульптури. Але ідея С. Воронова полягала у відтворенні різними чотирма художниками фарфорової справи (без можливості порівнювати результати на етапі проектування) 4-х варіантів розпису автентичних прототипів (вибір декору на власний розсуд 3 відомих різновидів розфарбування) та пропозицій 4-х взірців сучасного, індивідуально осмисленого та запропонованого авторського розпису. До того ж ці мисткині до 8-ми окреслених різновидів розділки пропонували розпис скульптурно промодельованих всіх 4-х типів пластичних наперстків, та форми наперстків №1 в стилі справдешнього Волокитиного.

У результаті автор ідеї та проекту С. Воронов обрав по 1-му кращому варіанту оформлення скульптури «Українка» в історичному ключі за першовзірцями заводу А. Міклашевського та 1-й новітній пропозиції декору означеної статуетки, а також по 1-му прикладу пластично промодельованих та оздоблених розписом наперстків і 1-му взірцю декорування наперстка форми №1 від кожної майстрині-художниці, і представив на виставці в НМУНДМ огляду широкої спільноти разом з унікальним артмініатюрним чайним сервізом в стилі волокитинського фарфору в розписі О. Жернової.

Форми цього сервізу є копією у зменшеному вигляді оригінального волокитинського сервізу межі 1840-х - 1850-х рр. В основі ідеї розпису лежить ідея «геральдичних квітів», яку автором почерпнув у високому європейському фарфорі Майсену, Дрездену, Відня, Севру та Херенду. Кожна квітка, що потрапила до цього «гербарію», мала свою історію і значення, відповідне смислове навантаження і символічний підтекст. Так, використані флореальні мотиви є системою знакових побажань і несуть семантичне навантаження.

Зокрема, мотиви, нанесені на наперстки підсилюються цими ж самими мотивами на сервізі, подвоюючи магічну силу квіткових символів. Тобто, тигрова лілея під девізом «Твоя гордість змушує мене страждати» - побажання скромності й лагідності; березки «Обіцяю тобі райську насолоду» - побажання гедоністичної складової життя, символ задоволення; ротики «Потребую твоєї прихильності» - формують доброчесність і милосердя; волошка «Довірся мені»- символізує захист і підтримку вищих сил; настурція «Я не відступлюся»формує такі риси характеру, як наполегливість, цілеспрямованість; братки (Анютині вічка) «Думаю про тебе постійно» - дають відчуття підтримки, запотребованості у суспільстві; жоржина (далія) «Розставання буде болісним для мене» - камертон вірності у коханні; незабудка «Пам'ятай про мене» - підсилює вогник кохання за рахунок нерозривного емоційного зв'язку між парою; бутон троянди «Готовий чекати нескінченно» - $є$ символом нескінченного палкого і пристрасного кохання на все життя; наперстянка «Готовий на будьякі жертви заради кохання» - алегорія відданості. Цей «райський сад кохання» в синтезі підсвідомо впливає на власника, формує його мисленнєві форми (мислеформи) в річищі долюбленості коханою людиною, повноцінного людського щастя, відчуття взаємності пристрасті.

На розсуд глядачів було представлено ансамблі унікальної оновленої «Українки» уособлення нації, образу дівчини з українського народу часів, коли визріло розуміння нашої ідентичності й було оспіване у прекрасному вишуканому гігієнічному матеріалі білосніжному фарфорі. Її свиту очолював ексклюзивний колекційний сервіз, ціну якому у художньому плані на сьогоднішній день навіть важко обрахувати. Адже це - реномова річ 
для збірок респектабельних поціновувачів, що як краща перлина в короні може бути єдиною окрасою виняткової краси матеріалу. Враховуючи, що виконання здійснене на надзвичайно високому рівні для найвибагливішого замовника, в ансамблі з ексклюзивними авторськими обереговими наперстками ці твори працюють на синтез мистецтв і сприймаються в симбіозі високих звершень пластики і розпису фарфору в стилі А. Міклашевського, аристократа по духу і естета за покликом душі й серця.

Наукова новизна. Розробка обгрунтування випуску елітарних виробів підприємства С. Воронова здійснювалась, відштовхуючись від концепції респектабельного подарунку, що виконаний у межах історичної спадкоємності культурної традиції і конкурує з провідними європейськими брендами. Тому кінцеві вироби є синтезом унікального скульптурного вирішення, декорованого ручним розписом надглазурними фарбами і золотом, випаленого у високому вогні. При цьому образний бік творів спирається на традиційну семантику української флори у неповторному варіанті стилізації, в якому віддзеркалюється мальовничість вітчизняної природи та ії колористичні особливості. Малотиражна серія тонко промодельованих наперстків є якісно новим продуктом на сучасному арт-ринку фарфорової мініатюри, відкриваючи нову нішу неповторних подарунків для знаменних дат і подій.

Насолода від споглядання цих творів мистецтва, розмір яких не перевищує заввишки 15 см, збільшується від розуміння ексклюзивності виконання речі, котра може бути виготовлена адресно, як унікальний твір для вибагливого замовника, за стародавніми технологіями високого фарфору з ручним розписом фахівцями високої кваліфікації.

Висновки Ідея здійснення в проекті меморіальної реконструкції української фарфорової статуетки, мініатюрного колекційного сервізу та розробки унікальних наперстків цієї серії була втілена за задумом С. Воронова у розрізі культурної пам'яті про національний мистецький феномен. Це стало можливим на хвилі зацікавлення сьогоднішнім суспільством гламуризованими персонажами волокитинських забавок-«цяцянок» $\mathrm{i}$ «фінтерлеїв» виробництва високого фарфору дворянина А. Міклашевського, діда першого українського гетьмана П. Скоропадського. Випуск такої високохудожньої сувенірної продукції нині дозволяє задовольнити потреби сучасних колекціонерів у творах реномової арт-мініатюри 3 «білого золота».

Перспективи майбутніх досліджень пов'язані з пошуком нових, альтернативних старим формам роботи, майже ювелірних різновидів виробів тонкої кераміки.

\section{Список використаних джерел}

1. Арапова Т. Б. Фарфор и керамика Китая. Санкт-Петербург: Государственный Эрмитаж, 2007. 35 c.

2. Дулькина Т. И., Ашарина Н. А. Русская керамика и стекло 18-19 веков. Москва: Изобразительное искусство, 1978. 328 с. : ил.

3. Жук М. И. История села Волокитино. 1964 год [Рукопись]. [Волокитино], 1964. [13 с.]. Из частного собрания.

4. Золотницький М. Ф. Квіти у легендах і переказах. Київ: Довіра, 1992. 207 с.

5. Кочерженко С. І. Волокитинський фарфор у Сумському художньому музеї. Харків: Прапор, 1971. 24 с. : іл.

6. Мусієнко П. Н. Замітки про враження з виставок народного мистецтва 1936-1957 pp. Матеріали про Волокитинський фарфоровий завод з 1842-1858 рр. Центральний державний архів-музей літератури і мистецтва Украӥни, ф. 990, оп. 1, спр. 392, 146 арк.

7. Миллер Дж. Антиквариат. Москва: Астрель, 2003. 304 с. : іл.

8. Петрякова Ф. С. Нові дані 3 історії фарфорового заводу у с. Волокитино Чернігівської губернії. Північне Лівобережжя та його культура у XVIII - поч. XX ст.: тези доповідей та повідомлення наук. конф., присвяченої 100-літтю від дня народження історика мистецтвв Ф. Л. Ернста (1891-1949). Суми, 1991. С. 30-32.

9. Решетньова Г. Фарфорові шедеври заводу Міклашевського в приватній колекції України. Традищї та новащиї у вищій архітектурно-художній освіті. 2017. Вип. 1. С. 100-116. 
10. Самецкая Э. Б. Фарфор завода Миклашевского. В. 2. т. Т.2. Москва: Интербукбизнес, 2010. 140 с. : іл.

11. Спаська Є. Ю. Старий український фарфор. Матеріали з етнографіï та мистецтвознавства. Київ: Вид-во АН УРСР, 1959. Вип. 5. С. 120-135.

12. Федевич Л. Пориеляна Волокитинської мануфактури Андрія Міклашевського. Каталог колекції Сумського художнього музею. Суми: ВТД «Університетська книга», 2005. 32 с. : іл.

13. Школьна О. В. Фарфор-фаянс Украӥни XX ст.: інфрраструктура галузі, пром. та економ. політика, організаційно-творчі процеси. Київ: Інтертехнологія, 2011. Кн. 1. 400 с.

14. Pearsall Ronald. Pottery \& Porcelain. Singapore: Smithmark publishers, 1997. 128 p.

\section{References}

1. Arapova, T. (2007). Farfor i keramika Kitaya [Porcelain and ceramics of China]. St. Petersburg: The State Hermitage.

2. Dulkina, T., Asharina, N. (1978). Russkaya keramika i steklo 18-19 vekov [Russian ceramics and glass of the 18-19th centuries]. Moscow: Fine Arts.

3. Fedevych, L. (2005). Portseliana Volokytynskoi manufaktury Andriia Miklashevskoho. Kataloh kolektsii Sumskoho khudozhnoho muzeiu [Porcelain of the Andrii Miklashevsky Volokytyne manufactory. The catalogue of the collection of the Sumy art museum]. Sumy: VTD «Universytetska knyha», 2005.

4. Kocherzhenko, E. (1971). Volokytynskyi farfor u Sumskomu khudozhnomu muzei [Volokytyne porcelain in the Sumy Art Museum]. Kharkiv: Prapor.

5. Miller, J. (2003). Antikvariat [Antiques]. Moscow: Astrel.

6. Musienko, P.N. Zamitky pro vrazhennia z vystavok narodnoho mystetstva 1936-1957 rr. Materialy pro Volokytynskyi farforovyi zavod z 1842-1858 rr. [Notes about the impressions from the exhibitions of folk art of 1936-1957. Materials about Volokytyne porcelain factory from 18421858]. Central state archive-museum of literature and art of Ukraine, f. 990 op. 1, sp. 392, 146 p.

7. Pearsall Ronald. (1997). Pottery \& Porcelain. Singapore: Smithmark publishers.

8. Petryakova, F.S. (1991). Novi dani z istorii farforovoho zavodu u s. Volokytyno Chernihivskoi hubernii. Pivnichne Livoberezhzhia ta yoho kultura u XVIII - poch. XX st. [New data on the history of the porcelain factory in the village Volokytyne of Chernihiv region. The Northern Left Bank and its culture at the beginning of the 18th-20th century]. Pivnichne Livoberezhzhia ta yoho kultura u XVIII - poch. XX st.: tezy dopovidei ta povidomlennia nauk. konf., prysviachenoi 100-littiu vid dnia narodzhennia istoryka mystetstv F. L. Ernsta (1891-1949), pp. 30-32.

9. Reshetnova, H. (2017). Farforovi shedevry zavodu Miklashevskoho v pryvatnii kolektsii Ukrainy [Porcelain masterpieces of the Miklashevsky factory in the private collection of Ukraine]. Tradytsii ta novatsii u vyshchii arkhitekturno-khudozhnii osviti, Issue 1, pp. 100-116.

10. Sametskaya, E. (2010). Farfor zavoda Miklashevskoho. V. 2 t. T. 2. [Porcelain of Miklashevsky factory. In 2 vols. Vol. 2.]. Moscow: Interbuk-business.

11. Shkolna, O. (2011). Farfor-faians Ukrainy XX st.: infrastruktura haluzi, prom. ta ekonom. polityka, orhanizatsiino-tvorchi protsesy [Porcelain-faience of Ukraine of the 20th century: infrastructure of the branch, industrial and economical politics, organizational and creative processes]. Kyiv: Intertekhnologiya.

12. Spaska, E. (1959). Staryi ukrainskyi farfor. [Old Ukrainian Porcelain] Materials from ethnography and art history, issue 5. pp. 120-135.

13. Zhuk, M. (1964). Istoriia sela Volokitino. 1964 hod [History of the village Volokytyne]. [Manuscript]. [Volokytyne]. From a private collection.

14. Zolotnytskyi, M. (1992). Kvity u lehendakh i perekazakh [Flowers in legends and stories]. Kyiv: Dovira.

(С) Школьна О. В., 2018 